\title{
Pemetaan Hidrogeologi dan Analisis Geokimia Air Tanah Cekungan Air Tanah (CAT) Kendal
}

\author{
Thomas Triadi Putranto이 ${ }^{1}$ Wahju Krisna Hidajat ${ }^{1}$, dan Sinatrya Diko Prayudi ${ }^{1}$ \\ 1Departemen Teknik Geologi, Fakultas Teknik, Universitas Diponegoro; e-mail: putranto@ft.undip.ac.id
}

\begin{abstract}
ABSTRAK
Cekungan Air Tanah (CAT) Kendal merupakan salah satu dari 31 cekungan air tanah yang terletak di wilayah Provinsi Jawa Tengah yang memiliki intensitas pemanfaatan yang tinggi. Oleh sebab itu, perlu adanya evaluasi kondisi hidrogeologi untuk mengetahui aspek kualitas maupun kuantitas dari air yang berada dalam CAT Kendal tersebut. Penelitian ini bertujuan untuk inventarisasi titik minatan air tanah di dalam wilayah CAT Kendal, pola dan arah aliran air tanah, kualitas air tanah dan menentukan asal usul air tanah. Metodologi yang digunakan mencakup pendekatan lapangan melalui pemetaan hidrogeologi serta analisis hidrokimia air tanah. Terdapat dua system akufier yaitu akuifer bebas dan akuifer tertekan. Hasil pemetaan hidrogeologi diperoleh 100 titik minatan hidrogeologi yang terbagi atas 73 titik sumur gali dan 2 titik mata air untuk serta 25 titik sumur bor untuk merepresentasikan sistem akuifer. Range nilai daya hantar listrik dari akuifer bebas dan akuifer tertekan yaitu $260-13.050262 \mu \mathrm{S} / \mathrm{cm}$ dan $1.788 \mu \mathrm{S} / \mathrm{cm}$. Nilai pH berkisar antara 6,3-8,3 dan 6.5-8.8. Pola aliran air tanah bergerak dari selatan ke utara mengikuti morfologi yang melandai ke arah utara. Kondisi litologi mempengaruhi fasies air tanah. Batuan vulkanik menyebabkan air tanah memiliki kandugan mineral kation $\mathrm{Ca}^{2+}$ dan $\mathrm{Mg}^{2+}$ dengan anion bervariasi. Sementara itu lapisan alluvium di daerah dataran akan menyebabkan air tanah kaya akan mineral sodium $\left(\mathrm{Na}^{+}\right)$dengan anion berupa klorida $(\mathrm{Cl})$ ataupun sulfat $\left(\mathrm{SO}_{4}^{2-}\right)$.
\end{abstract}

Kata kunci: Air tanah, Hidrogeologi, Kendal, Geokimia

\begin{abstract}
The Kendal Groundwater Basin (CAT) is one of 31 groundwater basins located in the Central Java Province with a very highintensity of the utilization. Thus, it is necessary to evaluate hydrogeological conditions to determine the groundwater both in quality and quantity aspects in the Kendal Groundwater Basin. This study aims to inventory groundwater interest points within the Kendal groundwater basin, groundwater flows direction, groundwater quality and determine the groundwater facies. The methods were a field campaign through hydrogeological mapping and groundwater samples testing for the physical and chemical content. The results conduct 100 hydrogeological interest points. They are 73 dug wells, 2 springs, and 25 deep wells to represent the aquifer systems. There are two aquifer systems, i.e., unconfined aquifer and confined aquifer. The EC values of the unconfined aquifer and confined aquifer are $260-13,050 \mu \mathrm{S} / \mathrm{cm}$ and $262-1,788 \mu \mathrm{S} / \mathrm{cm}$, respectively. At the same time, the pH value is 6.3-8.8 and 6.5-8.8. The groundwater flows from the south to the north following the morphology that is lowering to the south. Volcanic rocks cause groundwater consisting of major cations of $\mathrm{Ca}^{2+}$ and $\mathrm{Mg}^{2+}$ with varying anions. Meanwhile, the alluvium layer in the plains affects groundwater composition rich in sodium ( $\left.\mathrm{Na}^{+}\right)$with anions in the form of chloride $(\mathrm{Cl}-)$ or sulfate $\left(\mathrm{SO}_{4}{ }^{2-}\right)$.
\end{abstract}

Keywords: Groundwater, Hydrogeology, Kendal, Geochemical

Citation: Putranto, T.T., Hidajat, W.K., dan Prayudi, S.D. (2020). Pemetaan Hidrogeologi dan Analisis Geokimia Air Tanah Cekungan Air Tanah (CAT) Kendal. Jurnal Ilmu Lingkungan, 18(2), 305-318, doi:10.14710/jil.18.2.305-318

\section{Latar Belakang}

Air merupakan salah satu komponen pokok yang harus dipenuhi makhluk hidup dalam hal bertahan hidup. Manusia dalam hal ini tidak luput dari aspek pentingnya pemenuhan kebutuhan air. Keberadaan air yang umumnya dimanfaatkan manusia tersebar dengan jumlah sebanyak 50 miliar kubik kaki baik di atmosfer, laut, gletser, danau, sungai, maupun dalam tanah sebagai air tanah (McCuen, 1989). Apabila dilihat dari jumlah pemenuhan manusia dengan distribusi keterdapatan air, umumnya manusia melakukan ekstraksi air untuk kebutuhan air bersih yang berada di bawah tanah. Air tanah umumnya terakumulasi dalam suatu wadah yang disebut Cekungan Air Tanah (CAT), yang umumnya pola aliran airnya bergerak dari tekanan tinggi menuju tekanan rendah seperti percobaan hukum Darcy (Freeze and Cerry, 1979).

Penelitian terkait potensi air tanah telah banyak dilakukan oleh beberapa peneliti sebelumnya yakni Sener et al. (2005), Srivastava and Bhattacharya (2006), Thomas et al. (2009), Jha et al. (2010), Madan et al. (2010), Talabi and Tijani (2011), Hammouri et al. (2012), Kumar et al. (2016), Adeyeye et al. (2019). 
Peneliti-peneliti tersebut banyak menggunakan aplikasi remote sensing ataupun Sistem Informasi Geografis (SIG) dalam penentuan zona potensi air tanah. Sementara itu penelitian yang memanfaatkan data geokimia untuk mengetahui kondisi kualitas air tanah juga banyak diteliti seperti oleh Hamzah et al. (2010), Tirumalesh et al. (2010), Zhou et al. (2012) Putranto et al. (2017), Bäumle et al. (2019)

Indonesia sebagai negara dengan kepadatan penduduk yang tinggi, memicu akan tingginya pemenuhan kebutuhan air bersih, terutama yang berasal dari air tanah. Wilayah Indonesia sendiri terbagi menjadi 2 wilayah besar, yaitu daerah CAT dengan persentase $47 \%$ dan Non-CAT sebesar $53 \%$ (Kodoatie, 2012). Salah satu wilayah CAT yang ada di Indonesia dengan potensi serta pemanfaatan yang besar adalah Cekungan Air Tanah Kendal. CAT Kendal mengacu pada Permen ESDM No. 2 Tahun 2017 masuk ke dalam wilayah Provinsi Jawa Tengah, serta digolongkan dalam CAT lokal dalam kabupaten memiliki luas sebesar $404 \mathrm{~km}^{2}$. Wilayah CAT Kendal secara spesifik masuk dalam wilayah Kabupaten Kendal secara keseluruhan, dengan cakupan sebanyak 16 kecamatan (Gambar 1).

Wilayah CAT Kendal sendiri secara umum belum dikaji secara mendalam, baik keterdapatan jenis akuifer dari data lapangan, pola pergerakan, serta kualitas air tanahnya. Kajian terkait kondisi hidrogeologi pada hakikatnya penting sebagai acuan dalam melakukan pemanfaatan maupun upaya konservasi. Penelitian yang dilakukan pada wilayah CAT Kendal bertujuan untuk: memetakan dan menginventarisasi sebaran titik minatan hidrogeologi, mengetahui pola dan arah aliran air tanah, mengidentifikasi dan menganalisis kualitas kimia air tanah (Daya Hantar Listrik/DHL dan derajat keasaman/pH), serta fasies air tanah.

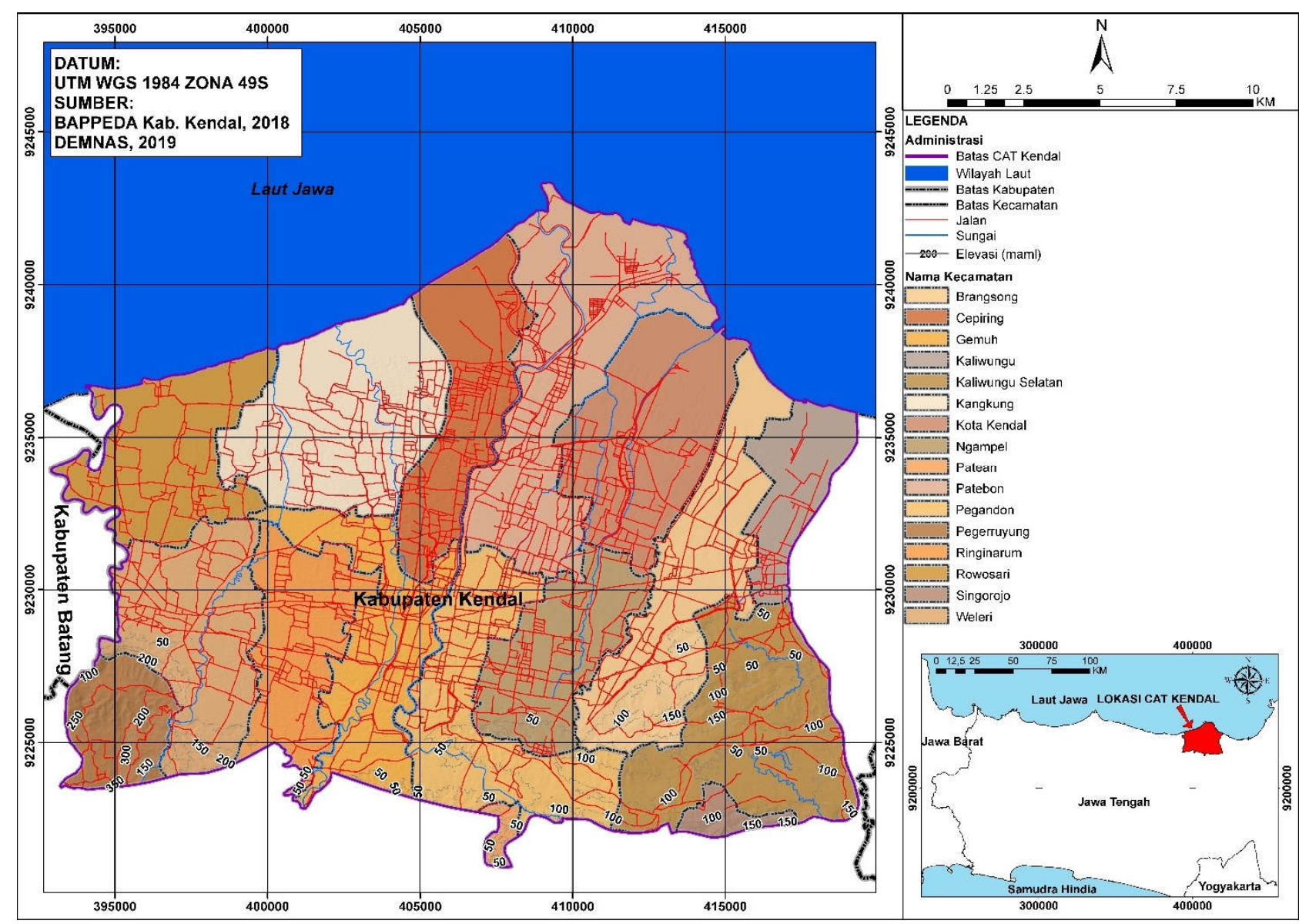

Gambar 1 Peta Administrasi dan Wilayah Studi Di Cekungan Air Tanah (CAT) Kendal

\section{Kondisi Geomorfologi, Geologi dan Hidrogeologi Regional}

Kondisi geomorfologi regional pada wilayah CAT Kendal digambarkan melalui kenampakan data digital elevation model yang diolah untuk mendapatkan nilai persen lereng dan derajat kelerengan. Acuan penentuan dari tiap jenis morfologi didasarkan pada klasifikasi morfologi menurut van Zuidam (1983). Wilayah CAT Kendal terdiri dari 6 jenis morfologi: datar/hampir datar; bergelombang landai; bergelombang miring; berbukit bergelombang; berbukit terjal; dan pegunungan sangat terjal. Persebaran secara umum dari jenis morfologi yang dihasilkan adalah kecenderungan morfologi yang kasar berada pada wilayah selatan sedangkan semakin halus dan landai di bagian utara. Untuk penjelasan dan gambaran dari masing-masing jenis dapat dilihat pada Tabel 1 dan Gambar 2. 
Kondisi geologi regional CAT Kendal berdasarkan peta geologi lembar Magelang-Semarang (Thanden dkk, 1996) tersusun oleh 3 formasi dari tua ke muda yakni: Formasi Kerek (Tme), Formasi Damar (QTd) dan Aluvium (Qa). Variasi batuan antara satu formasi dengan formasi lain berbeda. Formasi Kerek (Tmk) tersusun oleh litologi berupa perselingan batulempung, napal, batupasir tufan, konglomerat, breksi vulkanik, dan batugamping. Formasi kedua yaitu Formasi Damar (QTd) tersusun atas batupasir tufan, konglomerat, dan breksi vulkanik. Formasi Aluvium sebagai lapisan termuda umumnya terdiri atas kerikil, pasir, lanau dan lempung, endapan sungai dan rawa dengan ketebalan berkisar $150 \mathrm{~m}$.

Tabel 1. Tabel Pembagian Morfologi CAT Kendal Berdasarkan Klasifikasi van Zuidam (1983)

\begin{tabular}{clccccc}
\hline No & \multicolumn{1}{c}{ Morfologi } & $\begin{array}{c}\text { Persen } \\
\text { Lereng (\%) }\end{array}$ & $\begin{array}{c}\text { Kemiringan } \\
\text { Lereng ( })\end{array}$ & $\begin{array}{c}\text { Beda Tinggi } \\
(\mathbf{m})\end{array}$ & $\begin{array}{c}\text { Luas Satuan } \\
\mathbf{( k m}^{\mathbf{2}} \mathbf{)}\end{array}$ & $\begin{array}{c}\text { Persentase } \\
\text { Luas (\%) }\end{array}$ \\
\hline 1 & Datar/Hampir Datar & $0-2$ & $0-2$ & $<5$ & 130,5 & 32,3 \\
2 & Bergelombang Landai & $3-7$ & $2-4$ & $5-25$ & 111,9 & 27,7 \\
3 & Bergelombang Miring & $8-13$ & $4-8$ & $25-75$ & 105,8 & 26,2 \\
4 & Berbukit Bergelombang & $14-20$ & $8-16$ & $50-200$ & 43,6 & 10,8 \\
5 & Berbukit Terjal & $21-55$ & $16-35$ & $200-500$ & 11,7 & 2,9 \\
6 & Pegunungan Sangat Terjal & $56-140$ & $35-55$ & $500-1.000$ & 0,5 & 0,1 \\
\hline & & & & 404 & 100 \\
\hline
\end{tabular}

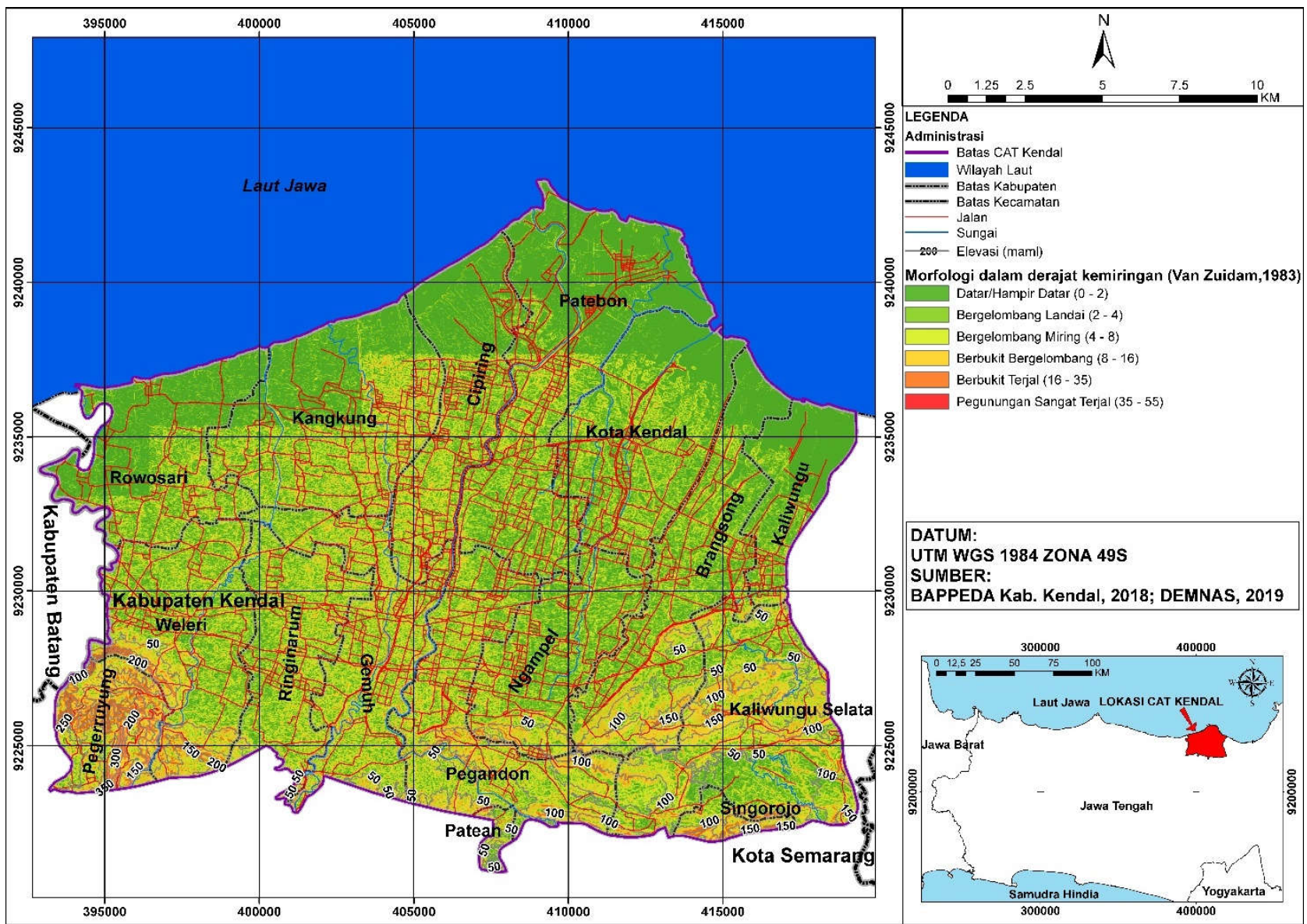

Gambar 2 Peta Morfologi Wilayah Cekungan Air Tanah (CAT) Kendal

Persebaran dari Formasi Aluvium berada pada wilayah utara, khususnya mulai dari wilayah dekat dengan pesisir hingga ke arah selatan hingga berbatasan langsung dengan Formasi Damar. Formasi Damar sendiri umumnya berada pada wilayah dengan topografi kasar dan berupa tinggian di bagian selatan wilayah CAT Kendal. Untuk Formasi Kerek ditemukan setempat di wilayah selatan, tepatnya di Kecamatan Ringinarum.
Kondisi hidrogeologi regional mengacu pada Peta Hidrogeologi Regional Indonesia saka 1:250.000 Lembar VI Pekalongan (Effendi, 1985) terbagi atas 2 sistem akuifer yaitu: akuifer dengan aliran melalui ruang antar butir dan akuifer dengan aliran melalui celahan dan ruang antar butir. Akuifer dengan aliran melalui ruang antar butir tersusun oleh akuifer dengan produktivitas tinggi dan persebaran luas; akuifer dengan prodiktif dengan penyebaran luas, dan akuifer dengan produksi sedang dengan penyebaran 
luas. Untuk akuifer dengan aliran melalui celahan dan ruang antar butir tersebar secara setempat dan termasuk akuifer produktif. Selain pembagian di atas, pada beberapa wilayah satuan terdapat bagian yang telah terjadi penggaraman atau kondisi rasa dari air yang asin karena bercampur dengan air laut. Untuk mengetahui persebaran satuan dan sub satuan hidrogeologi pada CAT Kendal dapat dilihat pada Gambar 4.

\section{Metodologi Penelitian}

Dalam kajian kondisi hidrogeologi yang dilakukan pada wilayah CAT Kendal terdapat beberapa tahapan yang perlu dilakukan seperti yang tertera pada diagram alir penelitian (Gambar 5). Tahap awal yang dilakukan mencakup studi literatur untuk memahami gambaran umum secara regional daerah penelitian. Selain kajian literatur, pada bagian awal juga dilakukan tahap persiapan alat dan bahan guna keperluan akuisisi data di lapangan serta melakukan tahap pengajuan izin penelitian kepada pemangku kebijakan maupun masyarakat sekitar daerah penelitian. Selanjutnya melakukan pengumpulan data lapangan. Teknis pengumpulan yang dilakukan mencakup pengambilan data kuantitatif dan kualitatif. Fokus pengambilan data baik kuantitas maupun kualitas mencakup data yang merepresentasikan akuifer bebas yang berupa sumur gali dan mata air, serta akuifer tertekan yang berupa sumur bor. Pengumpulan data kuantitatif mencakup data kedudukan titik minatan (koordinat) serta pengukuran kedudukan vertikal dalam titik minatan terkait air tanah. Keluaran hasil dari pengolahan data kuantitatif berupa peta persebaran titik minatan serta peta pola aliran air tanah, baik pada akuifer bebas maupun akuifer tertekan. Untuk data kualitas air tanah didapatkan dari pengujian sampel di lapangan serta pengujian di laboratorium, terutama parameter fisik dan kimia. Pengujian sampel lapangan mencakup DHL dan derajat keasaman ( $\mathrm{pH})$. Untuk pengujian sampel di laboratorium difokuskan pada data kimia ion terlatut. Data kualitas air tanah yang didapatkan dari lapangan diolah untuk mendapatkan persebaran distribusi nilai, baik DHL maupun $\mathrm{pH}$. Untuk hasil analisis laboratorium terkait kualitas air tanah digunakan untuk pembuatan diagram stiff dalam analisis ion dominan serta penamaan air tanah, dan pembuatan diagram piper dalam identifikasi fasies air tanah.

Dalam mengkaji kualitas air tanah, setidaknya terdapat dua parameter besar yang diperhatikan: parameter sifat fisik dan sifat kimia. Terkait dengan sifat fisik air tanah yang menjadi acuan analisis kualitas menurut Hadipurwo (2006) meliputi: warna (dipengaruhi zat terkandung dalam air); bau (ada tidaknya kandungan gas yang memicu perubahan); rasa (adanya kandungan garam atau zat lain yang mempengaruhi), kekentalan (dipengaruhi keberadaan partikel dalam air); kekeruhan (dipengaruhi keberadaan zat tidak terlarut dalam air); dan suhu (dipengaruhi keadaan sekeliling lokasi pengambilan).

Terkait dengan sifat kimia, terdapat beberapa aspek yang dikaji, yaitu: daya hantar listrik (Electrical Conductance atau $E C$ ), keasaman ( $\mathrm{pH})$, dan kandungan ion terlarut. Masing - masing aspek kimia air memiliki nilai ambang mulai dari rendah hingga tinggi sebagai acuan layak tidaknya air untuk kebutuhan manusia. Tabel 2 digunakan untuk klasifikasi daya hantar listrik yang terbagi menjadi 5 tipe, dari sangat buruk hingga sangat baik. Untuk nilai pH sesuai Permenkes No. 492/MENKES/PER/IV/2010 dengan acuan nilai standar 6,5-8,5. Aspek parameter terakhir berupa kandungan ion terlarut, di mana dalam mengkaji hasil keterdapatan ion yang muncul menggunakan acuan standar baku mutu oleh PERMENKES di atas. Identifikasi fasies air tanah menggunakan Diagram Piper (1944) yang dimodifikasi oleh Furtak and Langguth (1967) untuk penentuan fasies airt anah dan sebaran kondisi ion terlarut disajikan menggunakan Diagram Stiff (Stiff, 1951).

Tabel 2. Klasifikasi air berdasarkan daya hantar listrik Wilcox, (1955), Hem (1959), Zekai, (2015)

\begin{tabular}{cl}
\hline Daya Hantar Listrik $(\boldsymbol{\mu S} / \mathbf{c m})$ & \multicolumn{1}{c}{ Kualitas Air } \\
\hline$<250$ & Sangat Baik \\
$250-750$ & Baik \\
$750-2.000$ & Sedang \\
$2.000-3.000$ & Buruk \\
$\geq 3.000$ & Sangat Buruk \\
\hline
\end{tabular}




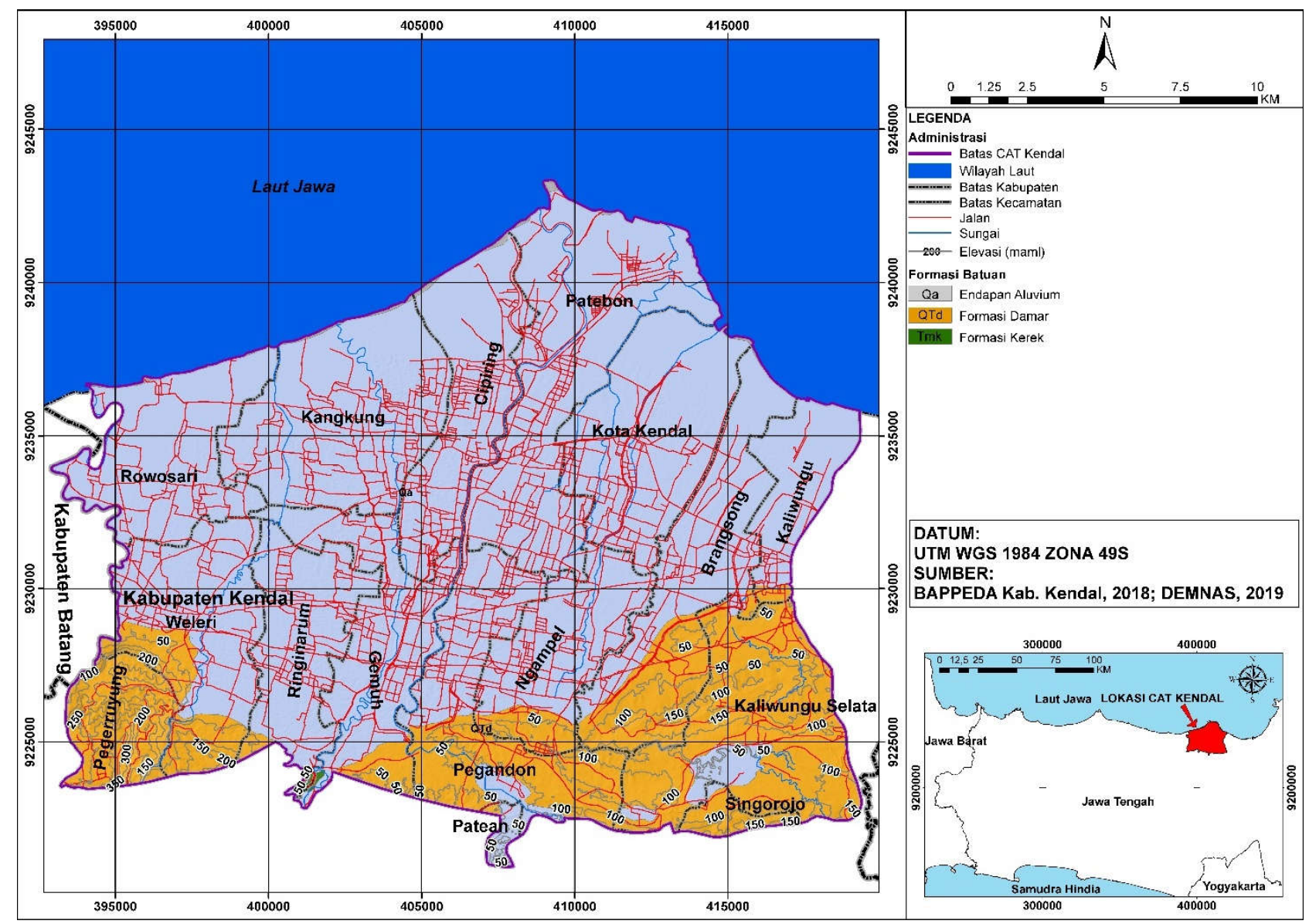

Gambar 3 Peta Geologi Regional Wilayah Cekungan Air Tanah (CAT) Kendal

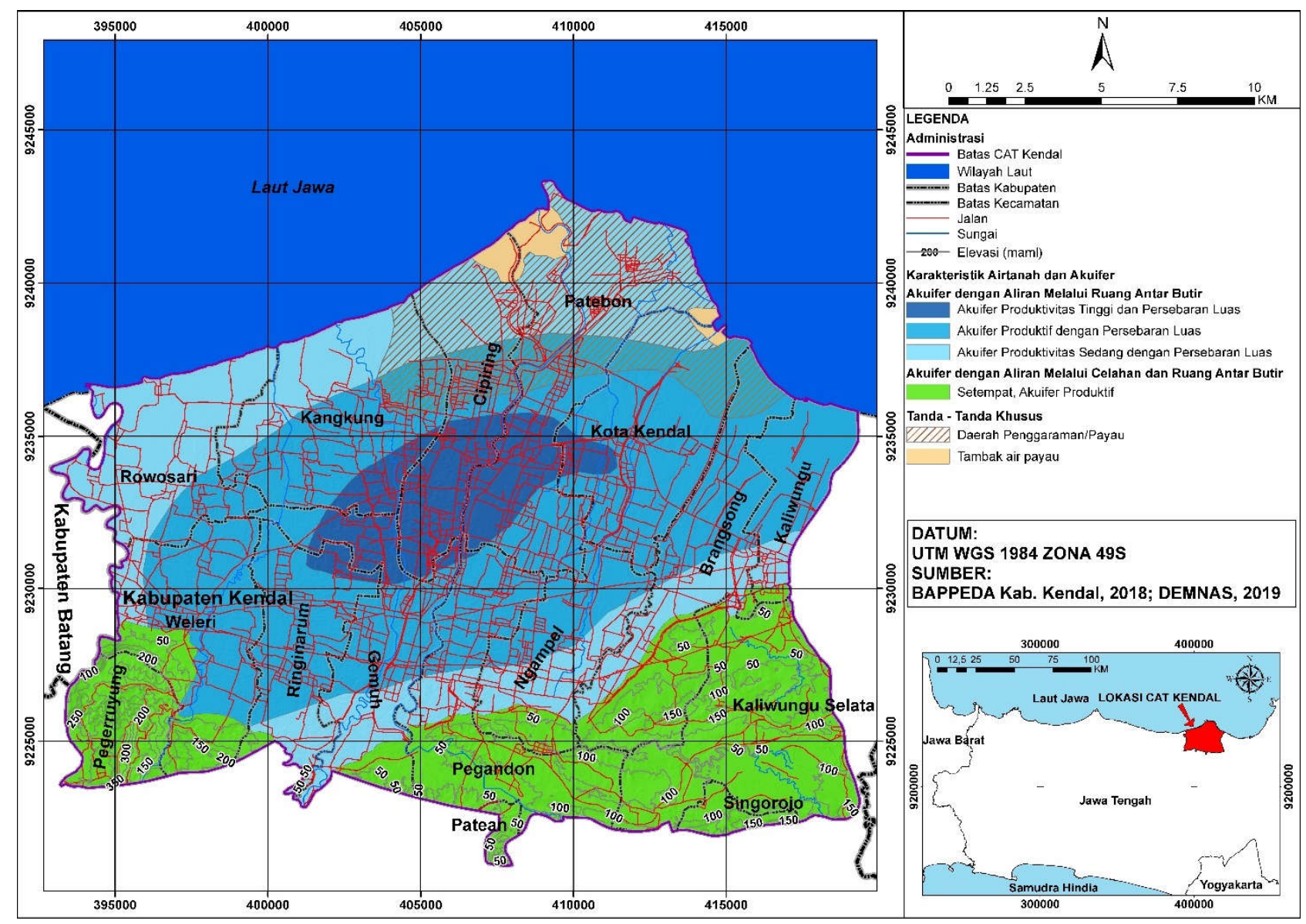

Gambar 4 Peta Hidrogeologi Regional Wilayah Cekungan Air Tanah (CAT) Kendal 


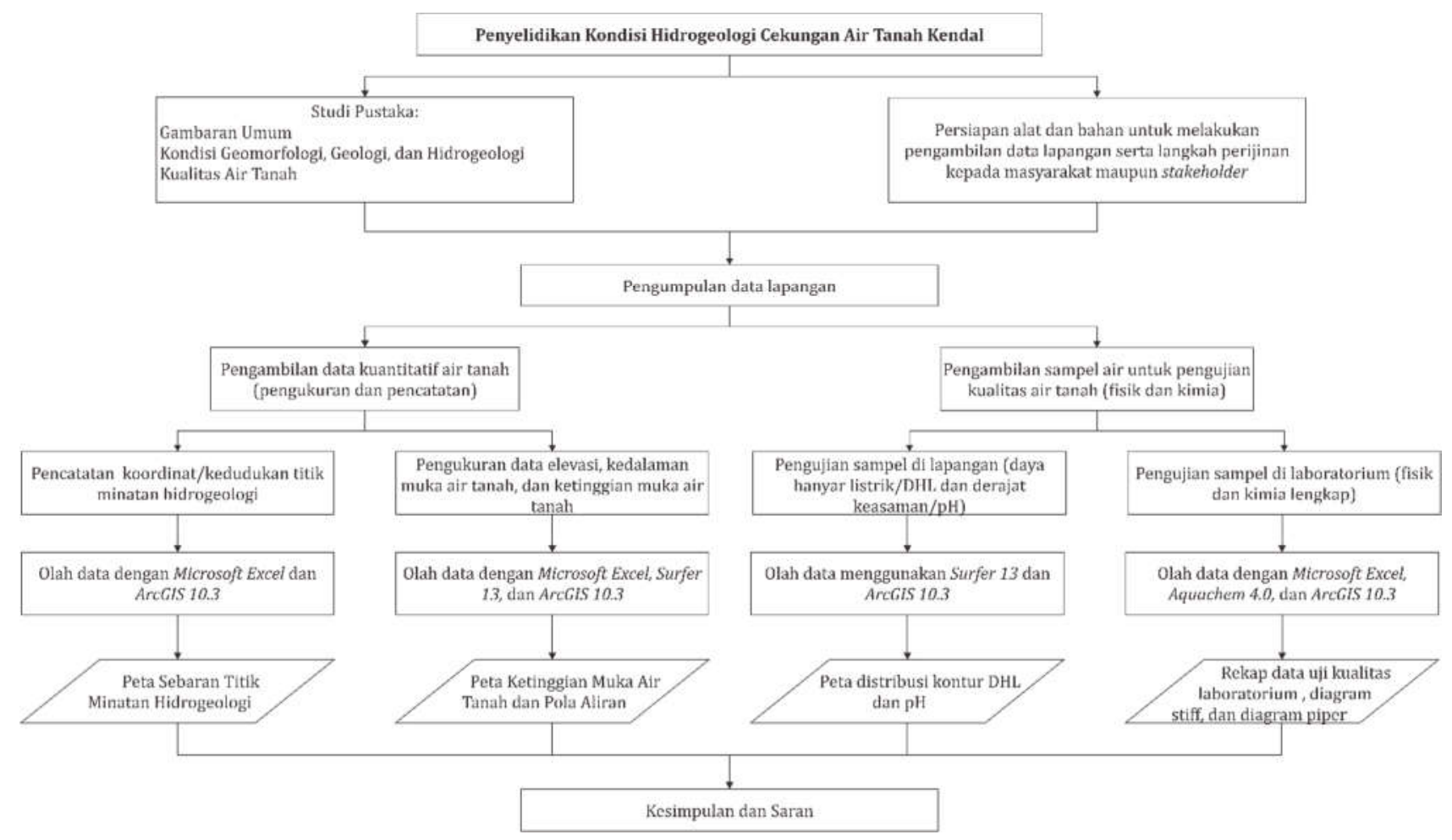

Gambar 5 Diagram Alir Penelitian

\section{Hasil dan Pembahasan}

\subsection{Inventarisasi Titik minatan}

Terkait data kuantitatif yang diperoleh dalam penelitian ini, dilakukan pencatatan koordinat titik minatan untuk menggambarkan persebaran titik minatan hidrogeologi melalui pemetaan lapangan. Data yang dikumpulkan baik akuifer bebas maupun tertekan sebanyak 100 sampel dengan distribusi: 73 titik minatan sumur gali (SG), 2 titik minatan mata air (MA), dan 25 titik minatan sumur bor (SB) seperti terlihat pada gambar 6 .

\subsection{Pola dan Arah Aliran Air Tanah}

Untuk melihat distribusi titik minatan baik akuifer bebas dan tertekan dapat dilihat pada Gambar 6 dan Gambar 7. Untuk data sumur gali sebagai representasi akuifer bebas, rentang ketinggian muka air tanah berada pada nilai (-)1,9 sampai 80,8 meter di atas muka laut (maml). Distribusi nilai yang rendah umumnya berada di wilayah dataran rendah pada bagian utara, kemudian berangsur mengalami peningkatan ke arah selatan menuju daerah tinggian.
Kondisi tersebut memicu pola pergerakan air tanah pada akuifer bebas. Pola aliran yang terbentuk menghasilkan pergerakan air tanah dari selatan ke utara. Pola tersebut didukung oleh kondisi morfologi pada wilayah CAT Kendal yang berupa tinggian di bagian selatan dan berangsur landai ke wilayah utara. Untuk melihat distribusi kontur ketinggian muka air tanah akuifer bebas serta pola aliran air tanahnya dapat dilihat pada Gambar 8.

Untuk sebaran ketinggian muka air tanah pada akuifer tertekan pada wilayah CAT Kendal, memiliki kesamaan pola dengan akuifer bebas. Ditinjau dari variasi nilainya, data ketinggian MAT piezometric pada akuifer tertekan CAT Kendal memiliki rentang dari (-)17 hingga 86 maml. Distribusi nilai ketinggian membentuk kecenderungan meninggi di bagian selatan dan semakin landai serta dalam di bagian utara. Pola kontur ketinggian MAT yang dihasilkan menghasilkan pola aliran air tanah yang bergerak dari selatan ke utara. Untuk lebih menjelaskan distribusi nilai tinggi MAT dan pola aliran air tanah dapat dilihat pada Gambar 9. 


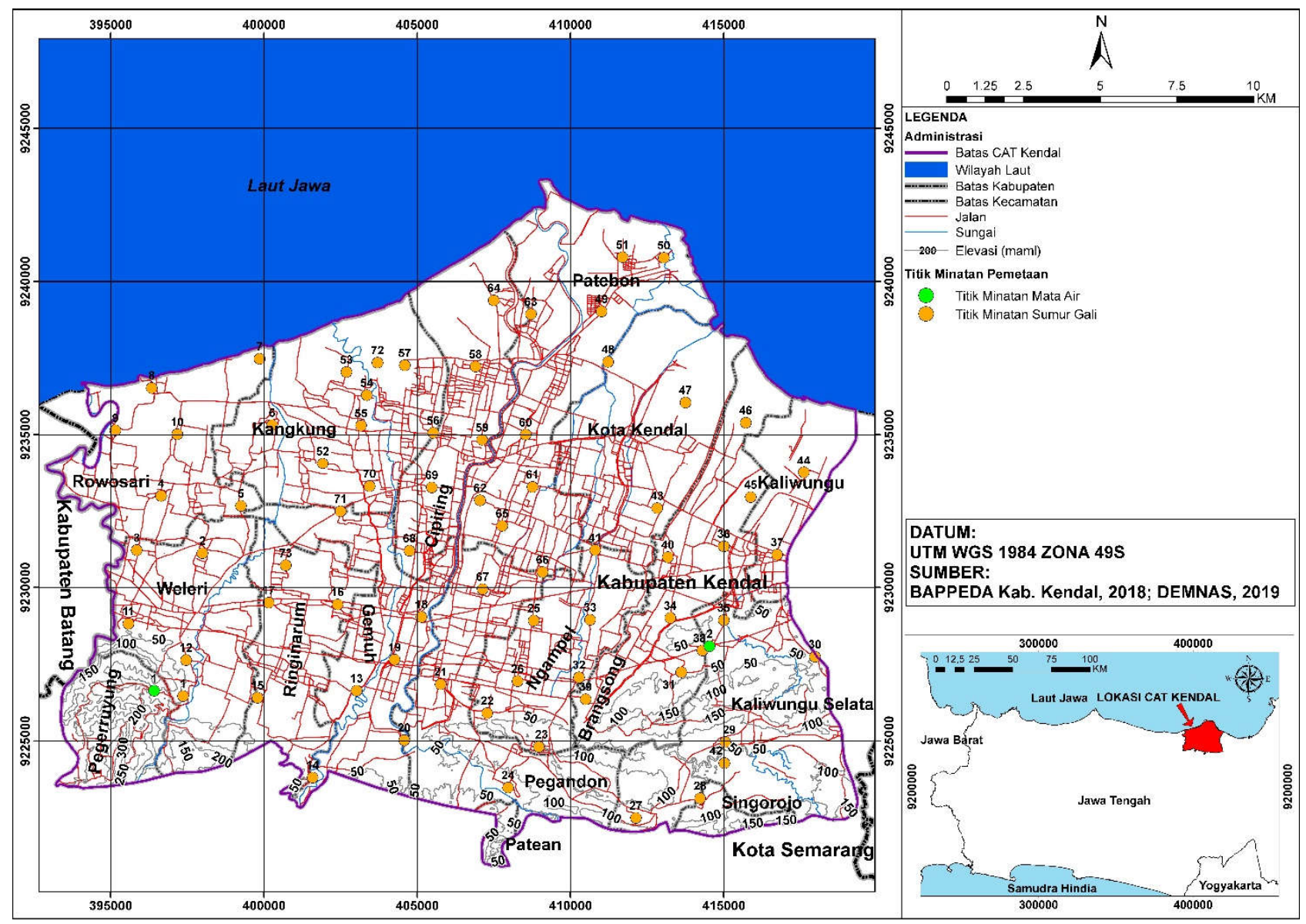

Gambar 6 Peta Sebaran Titik Minatan Akuifer Bebas CAT Kendal Meliputi Titik Sumur Gali dan Mata Air

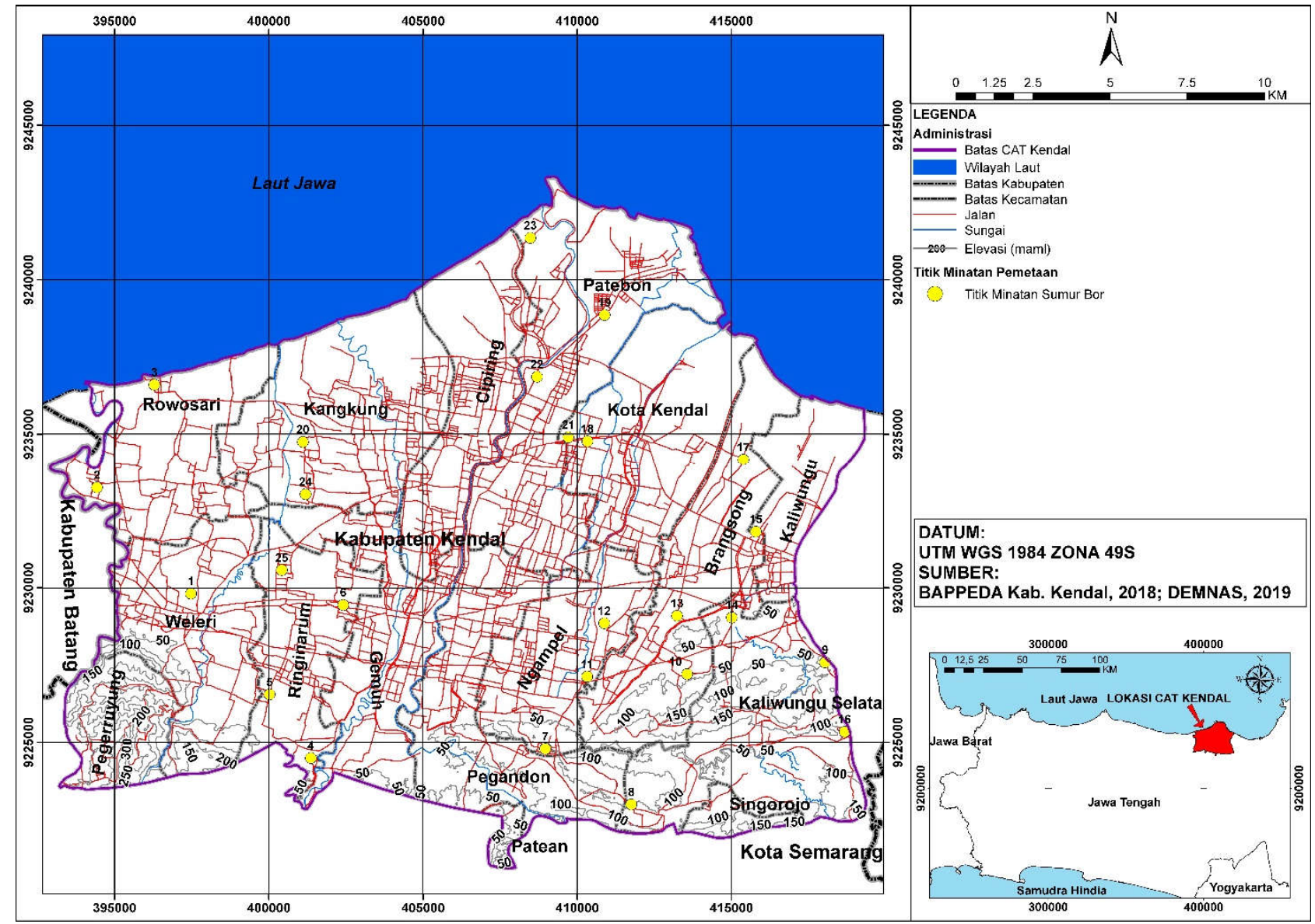

Gambar 7 Peta Sebaran Titik Minatan Akuifer Tertekan CAT Kendal Meliputi Titik Sumur Bor 


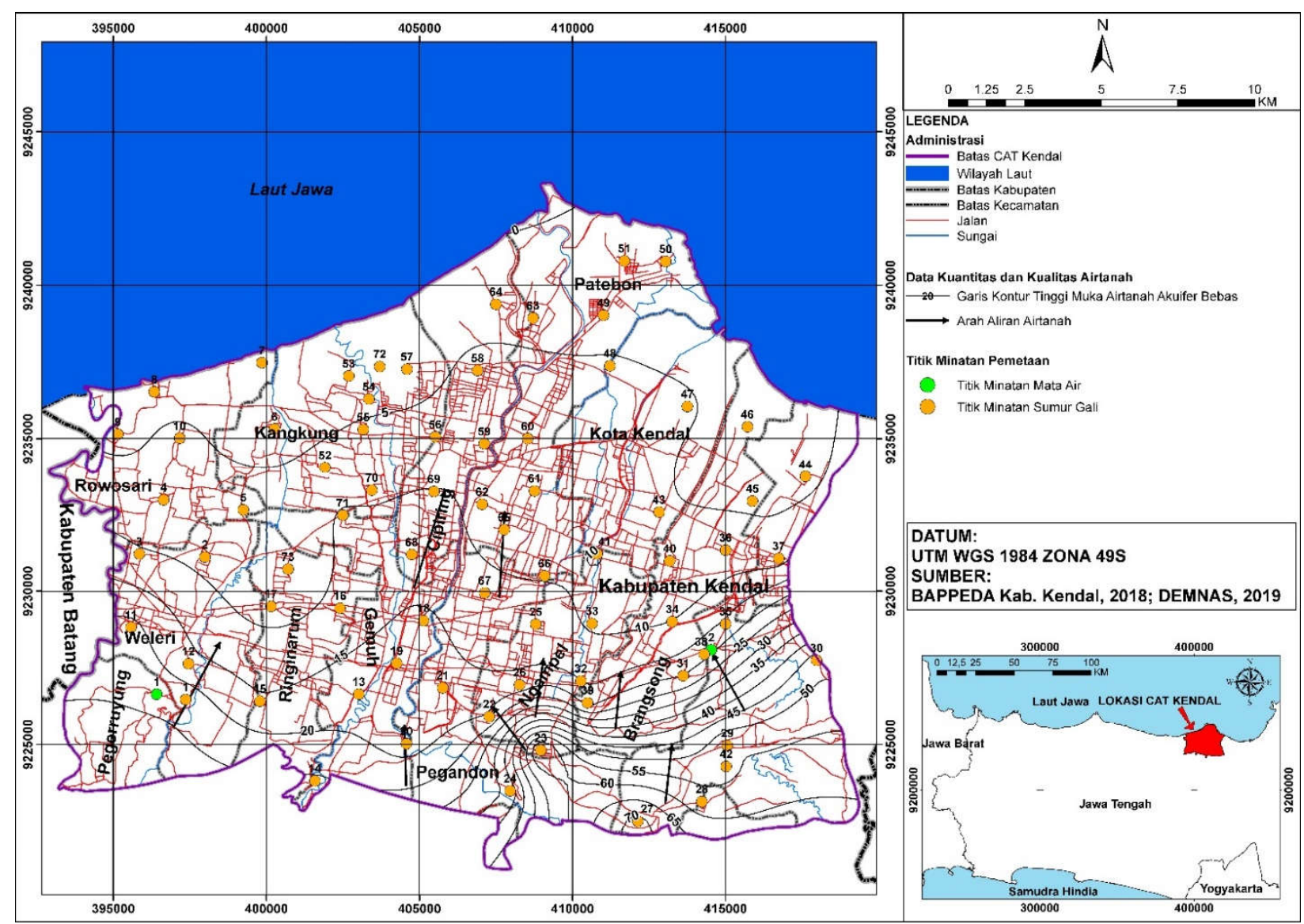

Gambar 8 Peta Kontur Ketinggian MAT dan Pola Aliran Air Tanah Akuifer Bebas CAT Kendal

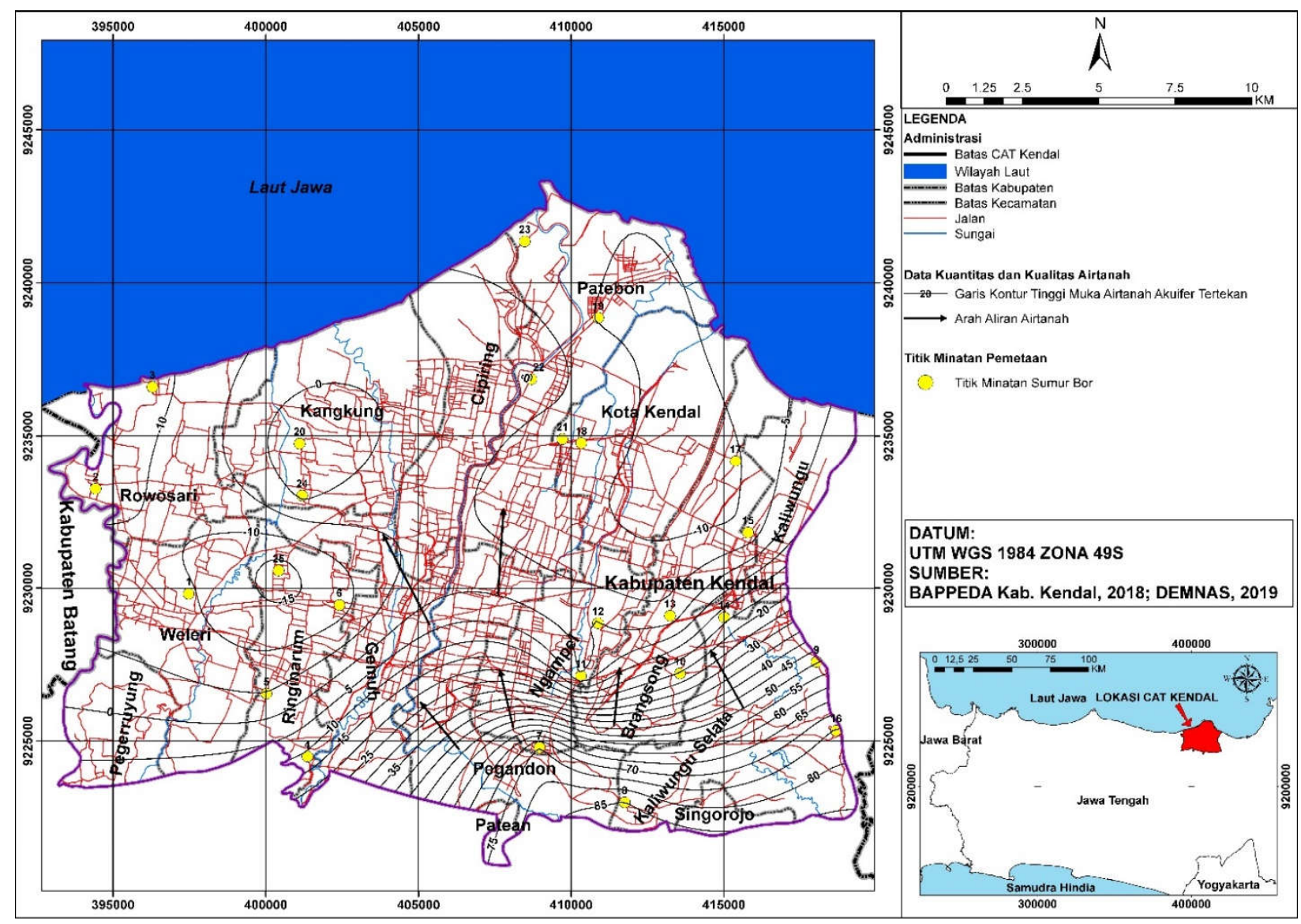

Gambar 9 Peta Kontur Ketinggian MAT dan Pola Aliran Air Tanah Akuifer Tertekan CAT Kendal 


\subsection{Analisis Kualitas Air Tanah}

Untuk nilai DHL pada akuifer bebas, rentang data yang diperoleh berada pada nilai 260-13.050 $\mu \mathrm{S} / \mathrm{cm}$, dengan nilai tertinggi terletak pada titik minatan SG 51. Apabila dihubungkan dengan klasifikasi air berdasarkan nilai DHL pada uraian Tabel 2, data akuifer bebas pada CAT Kendal dapat dibagi menjadi 4 tipe yaitu baik (250-750 $\mu \mathrm{S} / \mathrm{cm})$, sedang (750-2.000 $\mu \mathrm{S} / \mathrm{cm})$, buruk $(2.000-3.000 \mu \mathrm{S} / \mathrm{cm})$, dan sangat buruk $(>3.000 \mu \mathrm{S} / \mathrm{cm})$.

Persebaran nilai dengan kriteria baik berada di wilayah selatan CAT Kendal, kemudian mengalami peningkatan semakin ke selatan. Distribusi hasil DHL untuk akuifer bebas yang dihasilkan memberikan gambaran adanya pengaruh kondisi lingkungan terhadap tingginya nilai DHL. Kedudukan titik minatan dan daerah dengan nilai tinggi terletak pada wilayah pesisir. Kondisi tersebut mengindikasi pengaruh air laut terhadap air tanah pada bagian utara CAT Kendal.

Hasil pengukuran $\mathrm{pH}$ di lapangan untuk titik minatan akuifer bebas menghasilkan rentang nilai 6,3-8,3. Apabila mengacu pada Permenkes No. 492/MENKES/PER/IV/2010, data akuifer bebas secara umum masuk dalam rentang nilai aman, yaitu 6,5-8,5; meskipun terdapat nilai yang di luar batas. Titik minatan pada akuifer bebas dengan nilai di luar baku mutu yang tercatat berada pada titik minatan SG 1 dengan nilai 6,3 dan SG 29 dengan nilai 6,4. Untuk hasil overlay distribusi nilai DHL maupun $\mathrm{pH}$ akuifer tertekan serta keterdapatan daerah kecamatan yang menjadi cakupan dapat dilihat pada Gambar 10.

Untuk nilai DHL pada akuifer tertekan, rentang data yang diperoleh berada pada nilai 262-1.788 $\mu \mathrm{S} / \mathrm{cm}$, dengan nilai tertinggi terletak pada titik minatan SB 23. Apabila dihubungkan dengan klasifikasi air berdasarkan nilai DHL pada uraian Tabel 2 sebelumnya, data akuifer tertekan pada CAT Kendal dapat dibagi menjadi 2 tipe: baik $(250-750 \mu \mathrm{S} / \mathrm{cm})$ dan sedang $(750-2.000 \mu \mathrm{S} / \mathrm{cm})$. Persebaran nilai DHL yang masuk dalam kriteria baik terakumulasi pada bagian selatan, kemudian mengalami peningkatan seiring dengan kedudukan ke arah utara. Distribusi nilai yang dihasilkan memberikan indikasi adanya kecenderungan pengaruh luar terhadap peningkatan nilai DHL dari selatan ke utara.

Untuk akuifer tertekan terkait dengan derajat keasaman $(\mathrm{pH})$, rentang nilai yang didapatkan sebesar 6,5-8,8. Dengan acuan baku mutu yang sama, data untuk akuifer tertekan memiliki gambaran umum yang masuk dalam standar aman. Untuk titik dengan nilai melebihi standar berada pada titik minatan SB 19 dengan nilai 8,8. Untuk hasil overlay distribusi nilai DHL maupun $\mathrm{pH}$ akuifer tertekan serta keterdapatan daerah kecamatan yang menjadi cakupan dapat dilihat pada Gambar 11.

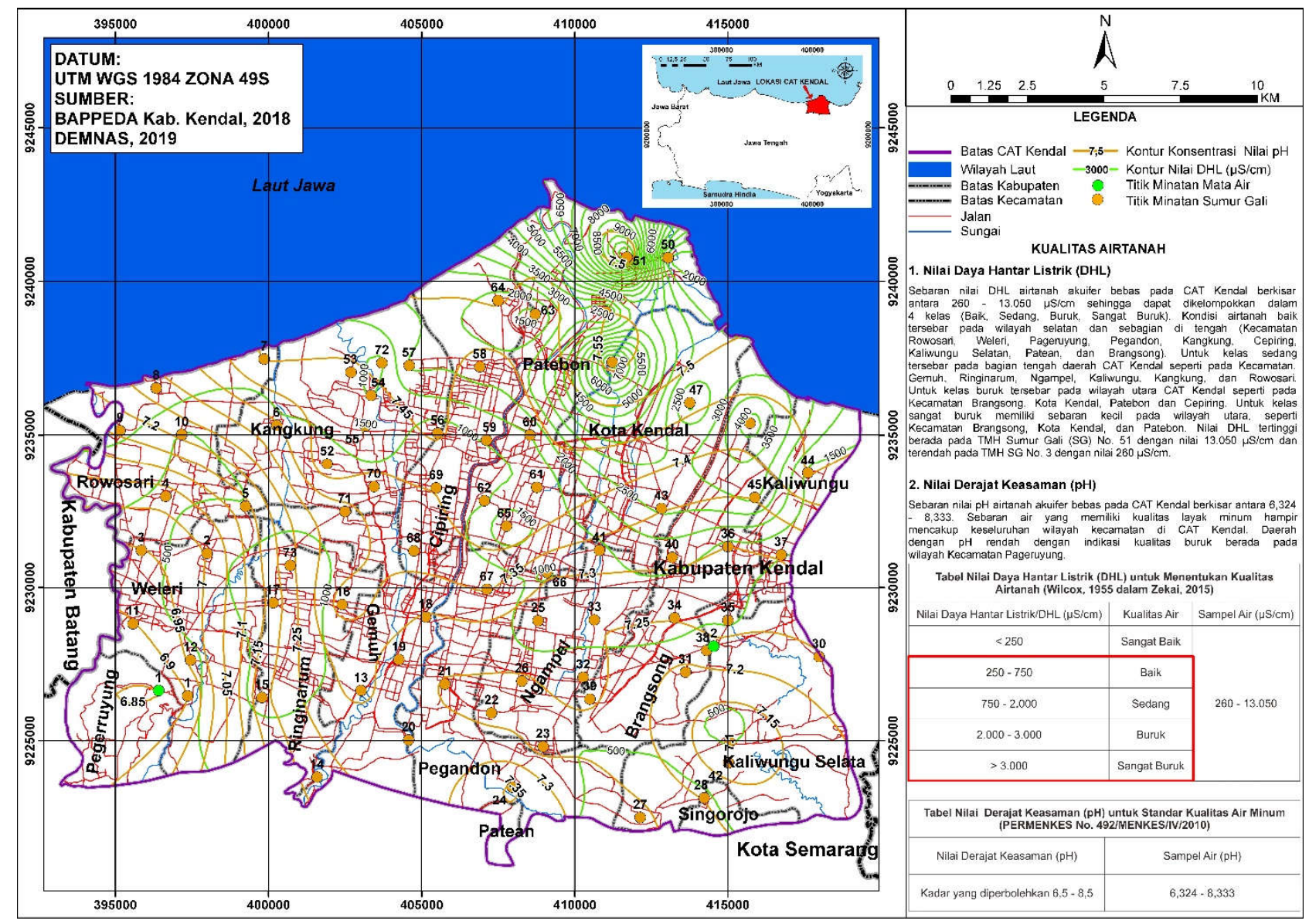

Gambar 10 Peta Overlay Kualitas DHL dan pH Akuifer Bebas CAT Kendal 


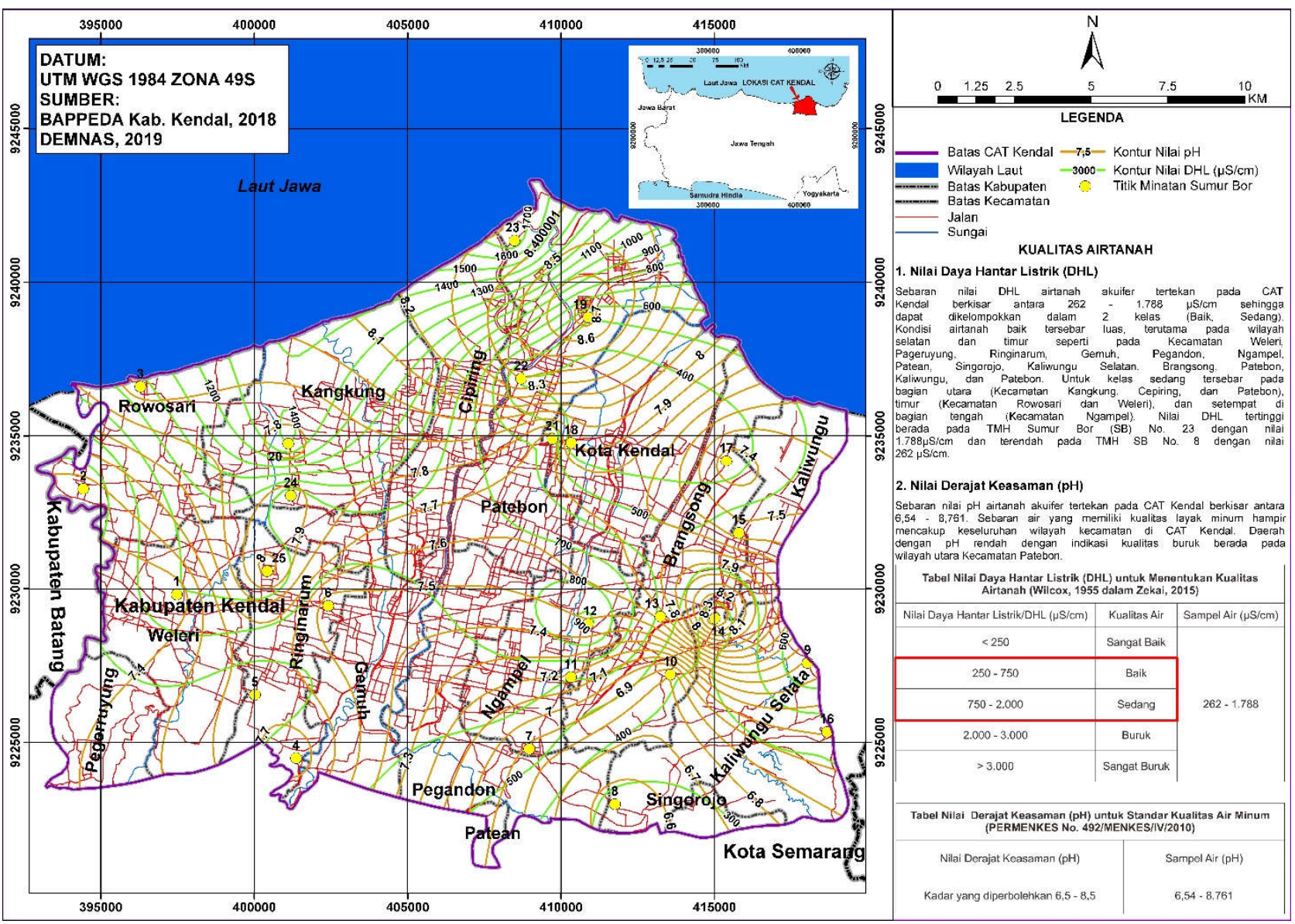

Gambar 11 Peta Overlay Kualitas DHL dan pH Akuifer Tertekan CAT Kendal

Analisis kimia terkait ion terlarut tertentu yang digunakan mencakup untuk kation berupa $\mathrm{Na}^{+}, \mathrm{K}^{+}$, $\mathrm{Ca}^{2+}$, dan $\mathrm{Mg}^{2+}$; sedangkan anion berupa $\mathrm{Cl}^{-}, \mathrm{HCO}_{3}$, dan $\mathrm{SO}_{4}{ }^{2-}$. Penggolongan nama air tanah lebih lanjut dibedakan distribusinya antara akuifer bebas dan tertekan. Data uji untuk penentuan nama air pada wilayah CAT Kendal total sebanyak 55 sampel uji, meliputi: akuifer bebas sebanyak 39 sampel, sedangkan untuk akuifer tertekan sebanyak 16 sampel. Penentuan nama didasarkan pada nilai dominasi dalam air yang melebihi $25 \%$ baik kation dan anion. Lebih lanjut, data ion dominan tersebut direpresentasi dalam bentuk diagram stiff dan dioverlay dengan sebaran titik minatan.

Untuk penamaan air tanah yang didapatkan dari hasil analisis ion terlarut akuifer bebas, dari 39 sampel air tanah yang diujikan didapatkan sebanyak 6 penamaan berdasarkan kation-anion dominannya disajikan menggunakan diagram stiff terlihat pada Gambar 12. Rincian dari tiap nama dan jumlah unit yang didapatkan meliputi: kalsium bikarbonat (Ca$\mathrm{HCO}_{3}$ ) sebanyak 1 sampel warna kuning, kalsium sulfat $\left(\mathrm{Ca}-\mathrm{SO}_{4}\right)$ sebanyak 1 sampel warna hijau muda,

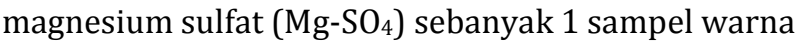
biru, Sodium klorida (Na-Cl) sebanyak 11 sampel warna jingga, sodium bikarbonat $\left(\mathrm{Na}-\mathrm{HCO}_{3}\right)$ sebanyak 1 sampel warna hijau tua, dan sodium sulfat $\left(\mathrm{Na}-\mathrm{SO}_{4}\right)$ sebanyak 24 sampel warna merah.

Untuk kation dominan yang berupa $\mathrm{Na}^{+}$berkaitan dengan akufier yang tersusun oleh Formasi Aluvium yang mendominasi wilayah CAT Kendal. Kation yang didominasi oleh $\mathrm{Ca}^{2+}$ dan $\mathrm{Mg}^{2+}$ memiliki litologi dominan Formasi Damar yang terletak di bagian selatan. Sebaran air tanah tipe anion $\mathrm{Cl}^{-}$dan $\mathrm{SO}_{4}{ }^{2-}$ mengindikasi tingginya proses penggaraman, sehingga banyak terdistribusi dominan di bagian utara.

Untuk penamaan air tanah yang didapatkan dari hasil analisis ion terlarut akuifer tertekan, dari 16 sampel air tanah yang diujikan didapatkan sebanyak 4 penamaan berdasarkan kation-anion dominannya. Rincian dari tiap nama dan jumlah unit yang didapatkan meliputi: sodium klorida (Na-Cl) sebanyak 5 sampel warna jingga, sodium sulfat (Na$\mathrm{SO}_{4}$ ) sebanyak 5 sampel warna merah, kalsium sulfat $\left(\mathrm{Ca}-\mathrm{SO}_{4}\right)$ sebanyak 1 sampel warna hijau muda, dan magnesium klorida (Mg-Cl) sebanyak 5 sampel warna ungu. Untuk mengetahui persebaran hasilnya dapat dilihat pada Gambar 13. 


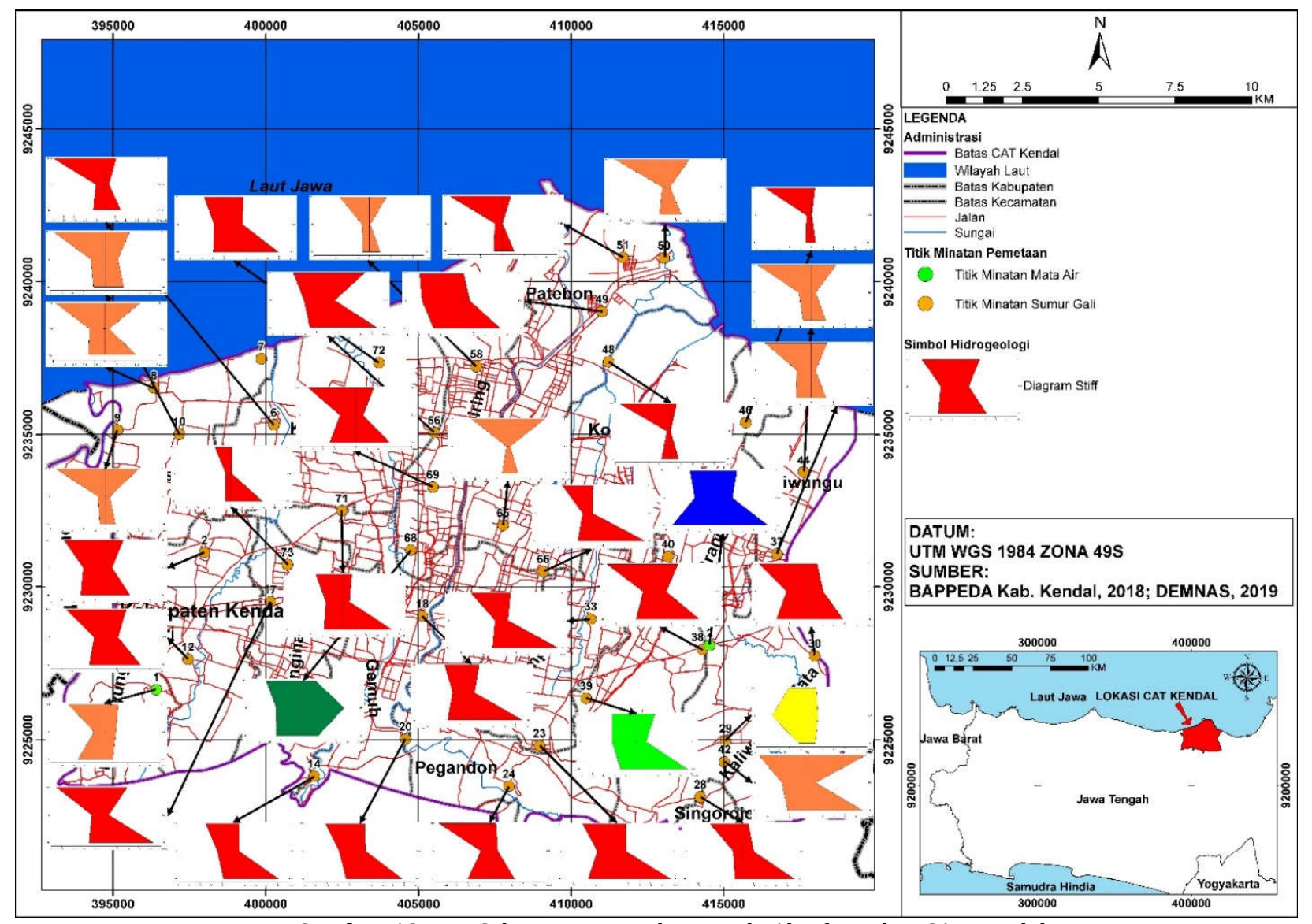

Gambar 12 Peta Sebarang Ion Terlarut Pada Akuifer Bebas CAT Kendal

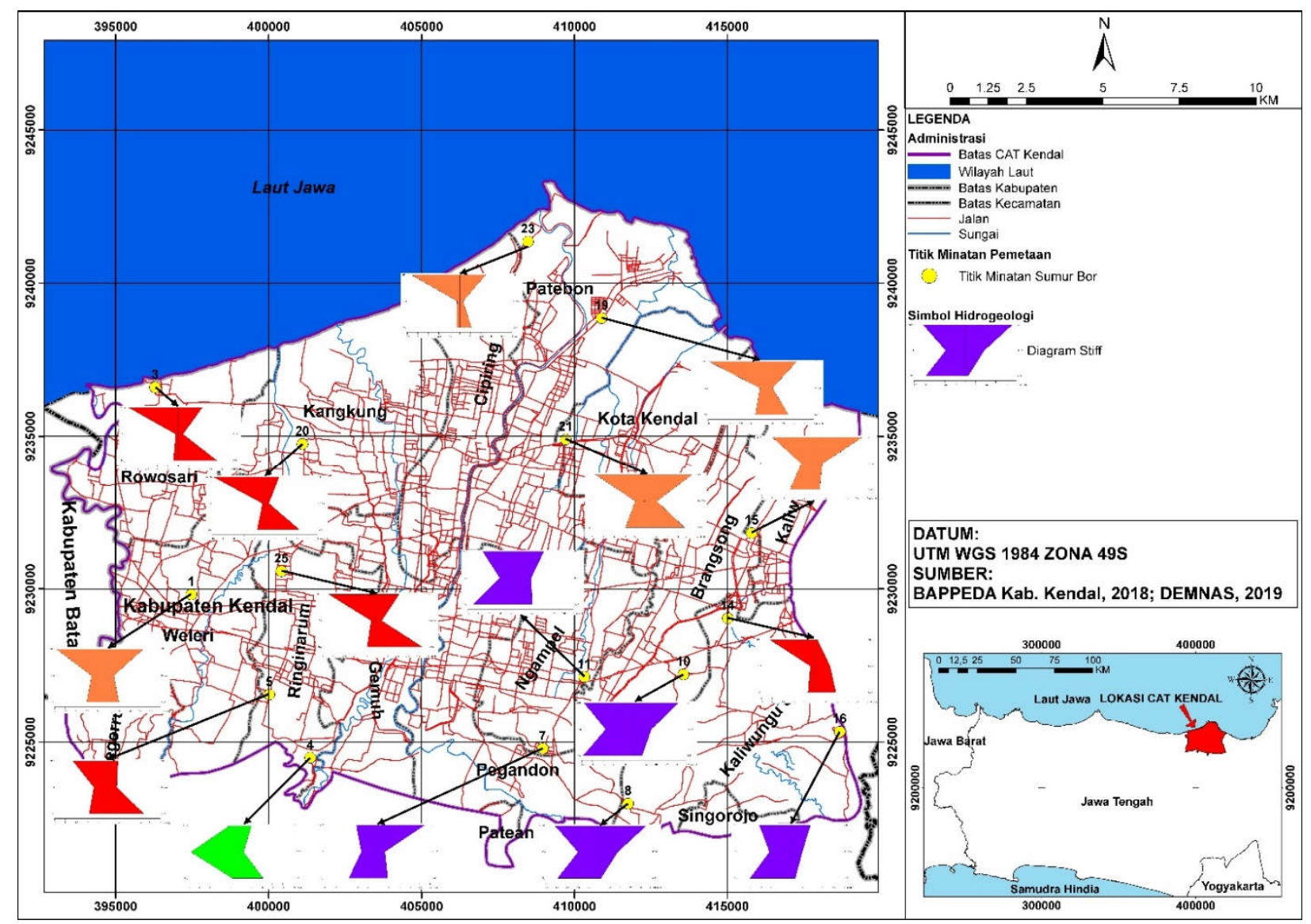

Gambar 13 Peta Sebarang Ion Terlarut Pada Akuifer Tertekan CAT Kendal 
Mengacu pada sebaran nama air tanah yang didapat dari data akuifer tertekan, dapat diketahui persebaran ion dominan cenderung merata. Karakterisasi anion dominan $\mathrm{Cl}^{-}$dan $\mathrm{SO}_{4}^{2-}$ sebagai indikasi pengaruh air laut terdistribusi di bagian utara. Keterdapatan kandungan ion $\mathrm{Ca}^{2+}$ dan $\mathrm{Mg}^{2+}$ pada air tanah setempat di wilayah selatan apabila diselaraskan dengan geologi regional, sesuai dengan sebaran Formasi Damar yang terdapat indikasi adanya batuan karbonat di bawah permukaan berdasarkan asosiasi formasinya. Untuk kation $\mathrm{Na}$ sendiri secara umum berasosiasi dengan batuan asal sedimen (Narany dkk, 2014).

\subsection{Fasies Air Tanah}

Acuan dalam penentuan fasies air tanah menggunakan data kimia ion terlarut berlandaskan pada analisis diagram trilinear yang dirumuskan oleh Piper (1944) dan dimodifkasi oleh Furtak and Langguth (1967). Mekanisme yang dilakukan adalah plotting titik pada diagram sesuai dengan dominasi ion (kation-anion) yang terdapat dalam air tanah. Baik anion maupun kation akan di-plot secara terpisah pada bidang di sisi kiri dan kanan, kemudian ditarik tegak lurus pada bidang utama di bagian tengah. Dalam pembagiannya, terdapat 3 fasies besar: Alkaline Earth Water dengan indikasi air tanah berasal dari daerah recharge atau imbuhan, Alkaline Earth Water Higher Alkaline Content dengan indikasi air tanah yang sudah bergerak menjauhi daerah imbuhan menuju hilir, dan Alkaline Water dengan indikasi kedudukan air tanah telah mencapai wilayah hilir suatu cekungan.

Untuk akuifer bebas, hasil pengolahan diagram piper diperoleh 3 fasies air tanah (Gambar 13). Fasies pertama adalah Alkaline Earth Water Higher Alkaline Content Predominantly Hydrogencarbonate, dengan jumlah sampel tersebar pada 1 titik. Fasies ini mencirikan asal air dari air hujan, dengan kecenderungan interaksi pada batuan yang kaya mineral lempung. Fasies kedua adalah Alkaline Earth Water Higher Alkaline Content Predominantly Sulphate, dengan jumlah sampel tersebar pada 14 titik. Fasies ini mencirikan air tanah yang terindikasi berinteraksi dengan air laut, dengan asosiasi batuan kaya mineral lempung berkomposisi $\mathrm{Mg}^{2+}, \mathrm{Ca}^{2+}$ dan pada beberapa kasus batuan vulkanik. Fasies ketiga adalah Alkaline Water Predominantly Sulphate Chloride, dengan jumlah sampel tersebar pada 24 titik. Fasies ini mencirikan air tanah yang berasosiasi dengan air laut dengan batuan pembawa kaya mineral lempung berkomposisi $\mathrm{Na}^{+}$dan $\mathrm{K}^{+}$.

Untuk akuifer tertekan, hasil pengolahan diagram piper diperoleh 3 fasies air tanah (Gambar 14). Fasies pertama adalah Alkaline Earh Water Predominantly Sulphate, dengan jumlah sampel tersebar pada 1 titik. Fasies ini mencirikan asal air tanah dari sumber air formasi atau telah berinterksi dengan air laut dan terakumulasi pada batuan volkanik kaya mineral $\mathrm{Mg}^{2+}$. Fasies kedua adalah Alkaline Earth Water Higher Alkaline Content Predominantly Chloride, dengan jumlah sampel tersebar pada 5 titik. Fasies ini mencirikan kandungan air tanah yang diperkaya oleh air garam klorida dan umumnya batuan-batuan sedimen yang kaya $\mathrm{Na}^{+}$. Fasies ketiga adalah Alkaline Water Predominantly Sulphate-Chloride, dengan jumlah sampel tersebar pada 10 titik. Fasies ini mencirikan asal air tanah yang mengalami pencampuran dengan air garam klorida, serta interaksi batuan yang kaya mineral lempung dari lapisan alluvium dominan $\mathrm{Na}^{+}$.

\section{Kesimpulan}

Pemetaan hidrogeologi dan analisis geokimia air tanah memberikan gambaran kondisi hidrogeologi di Cekungan Air Tanah (CAT) Kendal secara komprehensif. Pemanfaatan air tanah yang intensif di wilayah CAT Kendal tergambar dari banyaknya titik minatan yang dijumpai baik berupa sumur gali, mata air dan sumur bor. Sistem akuifer di wilayah CAT Kendal tersusun oleh sistem akuifer yang mengalir melalui ruang antar butir dengan litologi dominan berupa alluvium, sedangkan sistem akuifer yang mengalir melalui celahan dan ruang antar butir didominasi oleh produk vulkanik dari Formasi Damar. Di wilayah CAT Kendal terdapat 2 jenis akuifer yaitu akuifer bebas dan akuifer tertekan.

Pola dan arah aliran air tanah baik akuifer bebas dan tertekan mengalir dari arah selatan ke arah utara. Hasil pengukuran ketinggian dan distribusi elevasi muka air tanah didapatkan nilai: akuifer bebas sebesar (-)1,9 sampai 80,8 maml dan akuifer tertekan sebesar (-)17 sampai 86 maml.

Analisis kualitas air tanah terkait nilai DHL dan pH sampel akuifer bebas didapatkan nilai sebesar 260 hingga $13.050 \mu \mathrm{S} / \mathrm{cm}$ dan $\mathrm{pH}$ sebesar 6,3-8,3. Untuk kualitas akuifer tertekan nilai DHL sebesar 262 hingga $1.788 \mu \mathrm{S} / \mathrm{cm}$ dan $\mathrm{pH}$ sebesar 6,5-8,8. Kecenderungan pola yang dihasilkan adalah nilai semakin meningkat ke arah utara dengan indikasi pengaruh pencampuran air laut (mixing)

Kondisi litologi penyusun akuifer mempengaruhi fasies/asal usul air tanah. Sebaran mineral kation $\mathrm{Ca}^{2+}$ dan $\mathrm{Mg}^{2+}$ menyebabkan air tanah tersusun oleh alkaline earth water yang banyak terletak di daerah vulkanik dengan mineral anion berupa sulfat akan membentuk tipe Alkaline Earh Water Predominantly Sulphate. Sementara itu lapisan alluvium yang kaya akan mineral sodium $\left(\mathrm{Na}^{+}\right)$dengan anion berupa klorida $\left(\mathrm{Cl}^{-}\right)$ataupun sulfat $\left(\mathrm{SO}_{4}{ }^{2-}\right)$ akan membentuk air tanah bertipe Alkaline Earth Water Higher Alkaline Content Predominantly Chloride ataupun Alkaline Water Predominantly Sulphate-Chloride. 


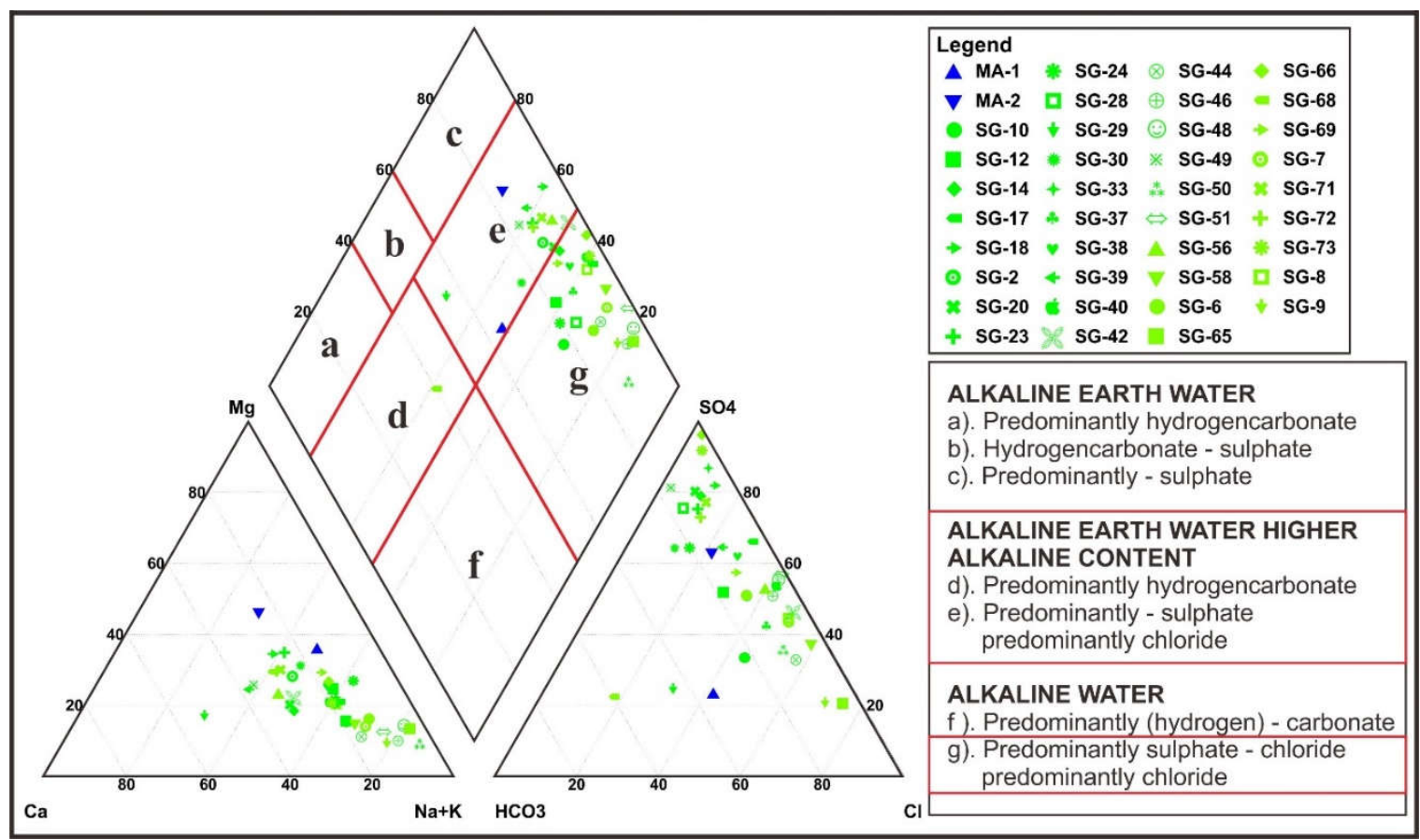

Gambar 14 Distribusi Hasil Analisis Fasies Air Tanah Akuifer Bebas Menggunakan Diagram Piper

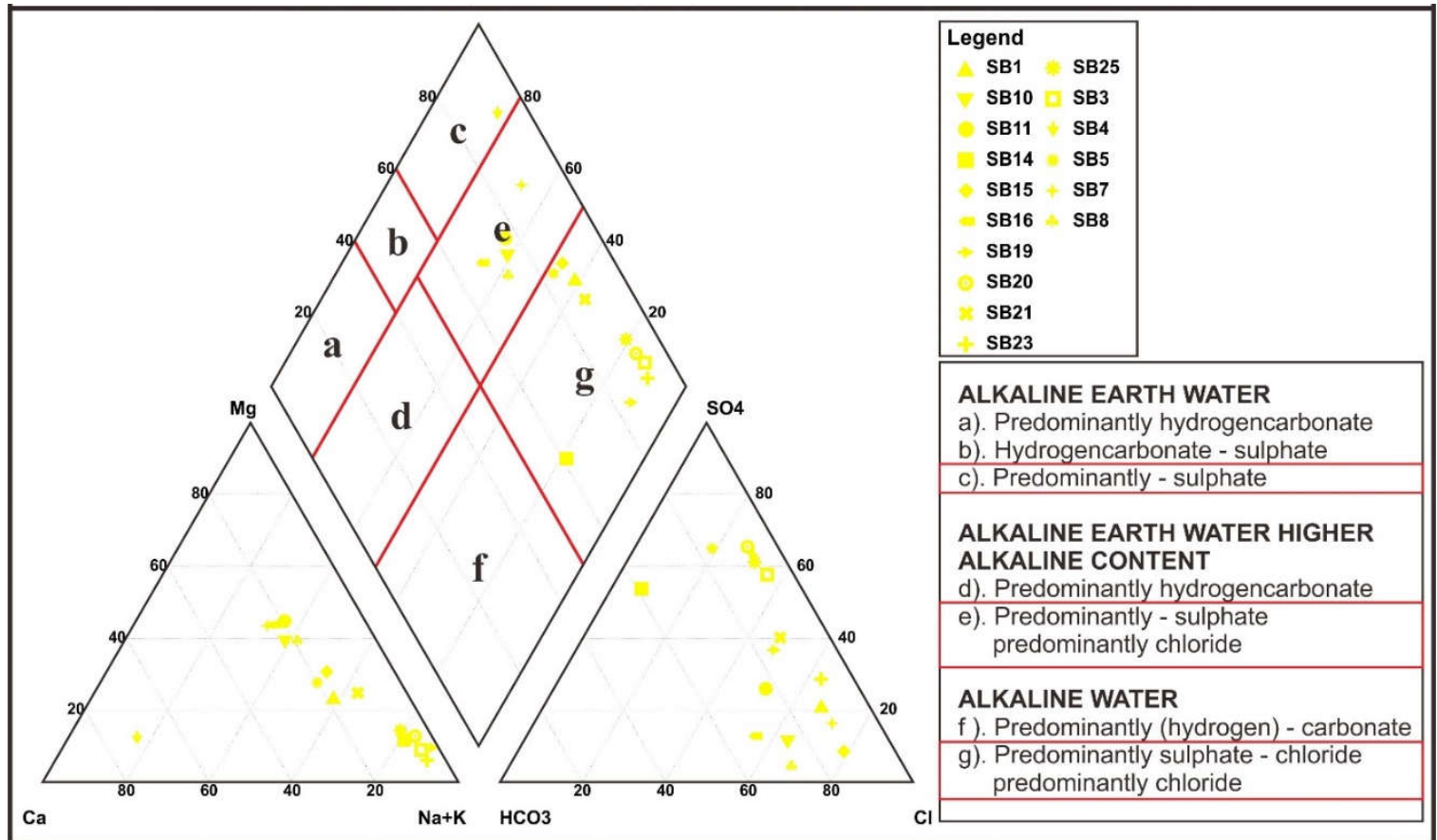

Gambar 15 Distribusi Hasil Analisis Fasies Air Tanah Akuifer Tertekan Menggunakan Diagram Piper

\section{UCAPAN TERIMAKASIH}

Ucapan terimakasih ditujukan kepada Universitas Diponegoro melalui pendanaan Riset Publikasi Internasional (RPI) sumber dana Selain APBN Universitas Diponegoro Tahun Anggaran 2020 dan Dinas Energi dan Sumber Daya Mineral Provinsi Jawa Tengah yang bersedia memberikan bantuan pelaksanaan penelitian ini.

\section{DAFTAR PUSTAKA}

Adeyeye, O.A., Ikpokonte, E.A., Arabi, S.A. 2019. GIS-based groundwater potential mapping within Dengi area, North Central Nigeria. The Egyptian Journal of Remote Sensing and Space Sciences 22 (2019) 175-181.
Bäumle, R., Himmelsbach, T., and Noell, U. 2019. Hydrogeology and geochemistry of a tectonically controlled, deep-seated and semi-fossil aquifer in the Zambezi Region (Namibia). Hydrogeology Journal (7):885-914.

Effendi, A.T. 1985. Peta hidrogeologi Indonesia Skala 1:250.000. Lembar VI (Pekalongan), Direktorat Geologi Tata Lingkungan, Bandung.

Freeze, R.A. and Cherry J.A. 1979. Groundwater. Prentice Hall-Internationl Inc., UK

Furtak, H. and Langguth, H.R. 1967. Zur hydrochemischen kennzeichnung von grundwässern und grundwassertypen mittels kennzahlen (Identification of hydrochemical types of groundwater aquifer using 
major ions). -Mem. IAH-Congress 1965. Hannover. VII: pp 86-96.

Hadipurwo. 2006, Konservasi sebagai upaya penyelamatan air tanah di Indonesia. Direktorat Pembinaan Pengusahaan Panas Bumi dan Pengelolaan Air Tanah, Direktorat Jenderal Mineral Batubara dan Panas Bumi, Departemen Energi dan Sumberdaya Mineral, Bandung.

Hammouri, N., El-Naqa, A., Barakat, M., 2012. An integrated approach to groundwater exploration using remote sensing and geographic information. Water Resour. Protect. 4, 717-724.

Hamzah, Z., Aris, A.Z., Ramli, M.F. 2017. Groundwater quality assessment using integrated geochemical methods, multivariate statistical analysis, and geostatistical technique in shallow coastal aquifer of Terengganu, Malaysia. Arab J Geosci 10 (49).

Hem, J.D. 1959. Study and interpretation of chemical characteristics of natural water: U.S. Geol. Survey Water-Supply Paper, 1473, 25 p.

Jha, K.M., Chowdary, V.M., Chowdhury, A., 2010. Groundwater assessment in Salboni Block, West Bengal (India) using remote sensing, geographical information system and multi-criteria decision analysis techniques. Hydrogeol J 18, 1713-1728.

Kodoatie, R.J. 2012. Tata ruang air tanah. Yogyakarta: Andi.

Kumar, P., Herath, S., Avtar, R., and Takeuchi, K. 2016. Mapping of groundwater potential zones in Killinochi area, Sri Lanka, using GIS and remote sensing techniques. Sustain. Water Resour. Manag. 2, 419-430.

Madan, K.J., Chowdary, V.M., Chowdhury A. 2010. Groundwater assessment in Salboni Block, West Bengal (India) using remote sensing, geographical information system and multi-criteria decision analysis techniques. Hydrogeol J 18(7):1713-1728.

McCuen, R. H. 1989. Hydrologic Analysis and Design. New Jersey: Prentice Hall.

Narany, T.S., Ramli, M.F., Aris, A.Z., Sulaiman, W.N.A., Juahir, H., and Fakharian, K. 2014. identification of the hydrogeochemical processes in groundwater using classic integrated geochemical methods and geostatistical techniques, in Amol-Babol Plain, Iran. The Scientific World Journal 1-15.

Piper, A.M. 1944. A Graphic procedure in the geochemical interpretation of water-analyses. Eos, Transactions American Geophysical Union, 25, 914-928.

Putranto, T.T., Hidajat, W.K., and Wijaya, H. hydrochemical assessment of unconfined aquifer system In Bayat Melange Complex, Klaten, Indonesia International Journal of GEOMATE, Nov., 2017, 13(39), 17-24.
Republik Indonesia. 2010. Peraturan Menteri Kesehatan No. 492/MENKES/PER/IV/2010 Tentang persyartan kualitas air minum.

Republik Indonesia. 2017. Peraturan Menteri Energi dan Sumber Daya Mineral No. 2 Tahun 2017, Tentang cekungan air tanah.

Sener E., Davraz, A., and Ozcelik, M. 2005. An integration of GIS and remote sensing in ground water investigations: a case study in Burdur, Turkey. Hydrogeology 13(5-6):826-834.

Srivastava, P.K., and Bhattacharya, A.K., 2006. Groundwater assessment through an integrated approach using remote sensing, GIS and resistivity techniques: a case study from a hard rock terrain. Int. J. Remote Sens. 27 (20), 4599-4620.

Stiff, H.A.Jr. 1951. The interpretation of chemical water analysis by means of patterns: Journal of Petroleium Technology, v. 3, no. 10, p. 15(17).

Talabi, A.O., and Tijani, M.N., 2011. Integrated remote sensing and GIS approach to ground-water potential assessment in the basement terrain of Ekiti area southwestern Nigeria. RMZ-Mater. Geoenviron. 58 (3), 303-328.

Thanden R.E., Sumadirja H., Richard P.W., Sutisna K. dan Amin T.C. 1996. Peta geologi lembar Magelang dan Semarang (1409-2, 1406-5), skala 1: 100.000, Jawa Tengah. Pusat Pengembangan dan Penelitian Geologi, Bandung.

Thomas, B.C., Kuriakose, S.L., and Jaydev, S.K. 2009. A method for groundwater prospect zonation in data poor areas using remote sensing and GIS: a case study in Kalikavu Panchayath of Malappuram district, Kerala, India. Int J Digit Earth 2(2):155-170.

Tirumalesh K., Shivanna K., Sriraman A.K., and Tyagi, A.K. 2010. Assessment of quality and geochemical processes occurring in groundwaters near central air conditioning plant site in Trombay, Maharashtra, India. Environ Monit Assess 163:171-184.

Van Zuidam R. A. 1983. Guide to geomoprhological aerial photographic interpretation and mapping. ITC Enschede, The Netherlands, pp 1-245.

Wilcox, L. V. 1955. Classification and Use of Irrigation Water. US Geol Dep Agri Arc.

Zekai, S. 2015. Practical and Applied Hydrogeology. Elsevier: Amsterdam.

Zhou Z., Zhang G., Yan M., and Wang J. 2012. Spatial variability of the shallow groundwater level and its chemistry characteristics in the low plain around the Bohai Sea, North China. Environ Monit Assess 184:3697-3710. 